
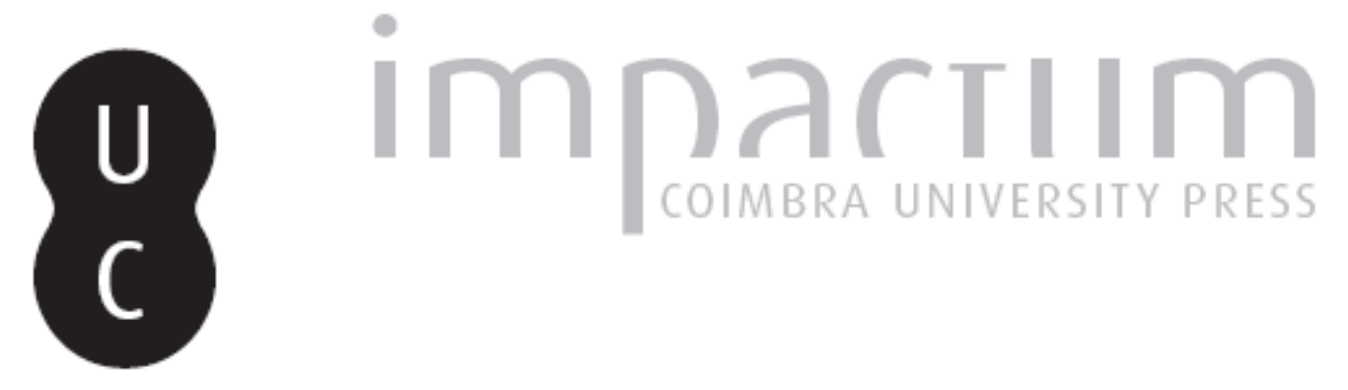

\title{
[Recensão a] J. Burckhardt, History of Greek Culture (Translated by Palmer Hilty), Dover Publications
}

\author{
Autor(es): Roskam, Geert \\ Publicado por: International Plutarch Society \\ URL \\ persistente: \\ URI:http://hdl.handle.net/10316.2/37583 \\ DOI: \\ DOI:http://dx.doi.org/10.14195/0258-655X_1_13 \\ Accessed : $\quad$ 26-Apr-2023 16:18:59
}

A navegação consulta e descarregamento dos títulos inseridos nas Bibliotecas Digitais UC Digitalis, UC Pombalina e UC Impactum, pressupõem a aceitação plena e sem reservas dos Termos e Condições de Uso destas Bibliotecas Digitais, disponíveis em https://digitalis.uc.pt/pt-pt/termos.

Conforme exposto nos referidos Termos e Condições de Uso, o descarregamento de títulos de acesso restrito requer uma licença válida de autorização devendo o utilizador aceder ao(s) documento(s) a partir de um endereço de IP da instituição detentora da supramencionada licença.

Ao utilizador é apenas permitido o descarregamento para uso pessoal, pelo que o emprego do(s) título(s) descarregado(s) para outro fim, designadamente comercial, carece de autorização do respetivo autor ou editor da obra.

Na medida em que todas as obras da UC Digitalis se encontram protegidas pelo Código do Direito de Autor e Direitos Conexos e demais legislação aplicável, toda a cópia, parcial ou total, deste documento, nos casos em que é legalmente admitida, deverá conter ou fazer-se acompanhar por este aviso.

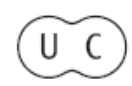


de l'héritage platonicien, dont témoigne à la même époque Aelius Aristide.

Toutes ces perspectives sont stimulantes. Elles ne manquent pas cependant de faire subir aux œuvres une certaine distorsion : la manière dont l'auteur applique sa problématique à des textes aussi divers, dans leur forme comme dans leur objectif, tend à réduire leur spécificité. La dimension satirique chez Lucien, ou encore la pluralité des approches chez Plutarque, se trouvent par exemple oblitérées, alors qu'il eût sans doute été éclairant de les exploiter. Soulignons ainsi à quel point la sélection opérée dans le corpus symposiaque de Plutarque restreint la complexité de ses conceptions. Sont ainsi éludées toutes les tensions, les nuances et les réflexions ludiques qui apparaissent dans les Propos de table -où, par exemple, le 'narrateur' va jusqu'à prendre la défense du solide appétit de son frère Lamprias (II, 2)! Que le plaisir alimentaire soit généralement dévalué, dans une perspective dualiste, c'est un fait. Mais l'interprétation en termes d'oubli est pour le moins forcée. La stratégie de Plutarque ne repose peut-être pas tant sur la logique du pharmakon platonicien telle que l'analyse J. Derrida que sur une forme de détournement, de déplacement : la nourriture est transférée de la sphère de la consommation à celle de la conversation. Le deîpnon quant à lui est parfois évoqué comme le moment de surgissement de la question, dont l'examen est alors reporté au symposion. La convention littéraire que ce décalage dénote avait déjà été évoquée par Florence Dupont, et ne peut se résumer à l'obsession du silence alimentaire.

LaETITIA Demarais

\section{J. BurCKHARDT, History of Greek Culture (Translated by Palmer Hilty), Dover Pu- blications, Mineola, New York, 2002. xi + 426 pp. ISBN 0-486-42096-5.}

J. Burckhardt never saw the publication of his monumental work about the history of Greek culture - actually he did not wish to see it ${ }^{1}$. His classic work Griechische Kulturgeschichte was first published posthumously in 1898 and 1902 by J. Oeri. From the very beginning, the work caused much turmoil in scientific circles, and was the target of many violent, and often justified, attacks. Nonetheless, it remained popular and was again and again reprinted. In 1958, an abridged version was published under the title Griechische Kultur. In the meantime, the book and its author had gradually become themselves objects of much scholarly research ${ }^{2}$. The shorter German version was first translated into English in 1963 (New York), and is now reprinted by Dover. Habent sua fata libelli...

No doubt, a presentation of the rich content of this famous book is hardly necessary, and can be reduced to a minimum. The first part ("State and Nation") is about general aspects of the origin, organisation and development of the Greek poleis. Next to two chapters on subservient people and slaves, most attention is given to different political 
constitutions (kingship, aristocracy, tyranny and democracy): their historical evolution, their typical characteristics and the way in which they took shape in a concrete historical context are discussed at length. B. does not limit himself to Sparta and Athens, but offers a wealth of information about the situation in other local poleis as well. The first part ends with a concise survey of Greek political thinking and a chapter about the unity of the Greek nation.

In the second part ("The fine Arts"), which is the shortest of the work, B. first deals with the earliest developments of works of art, as influenced by previous achievements in poetry and sophrosyne. Then, he presents a general picture of Greek sculpture (statues and reliefs of gods, individuals and groups), painting and architecture (esp. temple architecture), including a great deal of external description, often in contradistinction to the Egyptian or Mesopotamian works of art, and with attention to historical evolutions. A short discussion of the relation of philosophers and politicians with art closes this part.

The third part ("Poetry and music") begins with a short chapter on the earliest origins of poetic compositions. In the following chapter, B. first gives a personal presentation and evaluation of the content, composition and epic techniques of Ilias and Odyssey (which are both ascribed to the same poet), and then gives a rough sketch of Homer's extremely great importance for later generations and of the subsequent phases of hexametrical poetry (including the Homeric Hymns, Cyclic poets, narrative poetry of Alexandria (Apollonius and Callimachus, who receive a quite negative evaluation) and bucolic poetry). The chapter closes with a concise discussion of didactic poetry (mainly Hesiod, but also philosophical treatises, scientific works and even versified cookbooks). After a short chapter about the music and dance of the ancient Greeks, and their attitude towards it, B. deals with poetry in other measures than that of the hexameter: there are sections on elegy, epigram, iambic poetry, Aeolic and choral lyric, a somewhat more elaborate section on tragedy, and presentations of the Old, Middle, New and Alexandrian comedy.

In the final, fourth part ("On philosophy, science, and oratory"), B. first describes in broad outline the gradual break with the traditional myths in pre-Socratic philosophy up to the sophists. The introduction of the latter leads to a short chapter on Greek rhetoric. Then, philosophy once again comes to the fore: the philosopher appears as a free, independent personality (paradigm par excellence is of course Socrates, but his successors again and again gave evidence of the same attitude of independence). A brief overview of the scientific investigations of the Greeks, and their history and ethnology closes the corpus.

Added at the end of the carefully edited work are a glossary and 80 illustrations. Another 25 black-and-white line illustrations are inserted here and there in the main text. There is no bibliography, and only few direct references to primary and secondary sources in the whole work. When they occasionally appear, their presence is often rather arbitrary and more than once less necessary than at other places where they remain absent.

In general, B.'s presentation is detailed enough to avoid too great generalisations and over-simplifications, and yet general enough so as not to be lost in too specialized questions. It shows a careful balance between contagious enthusiasm (which becomes evident in many superlatives) and sound realism. Very often, B. gives evidence of his own wide reading through comparisons with both ancient and later cultures. This certainly adds to the quality of the Gesamtbild which B. presents to his readers, and which, though it will ultimatedly leave 
the modern specialist unsatisfied, can in any case serve as a good introduction for every none-specialist who is interested in the history of Greek culture.

\section{GeERT Roskam}

SAGE AND EMPEROR. Plutarch, Greek Intellectuals, and Roman Power in the Time of Trajan (98-117 A. D.), ed. by P. A. StadTer \& L. VAN Der StockT, Symbolae Facultatis Litterarum Lovaniensis Vol. 29, Leuven University Press, 2002. 357 pp. ISBN 90-5867-239-5.

Deux ans après la rencontre de Chapel Hill, en juin 2000, la majorité des communications présentées sont désormais réunies dans un volume des Symbolae des Presses universitaires de Leuven édité par P. A. Stadter et L. Van der Stockt. Le sujet choisi invitait à s'interroger sur la manière dont Plutarque fut ou ne fut pas "un philosophe dans le siècle", pour reprendre le sous-titre de la récente biographie de J. Sirinelli. Le titre même du volume marquait bien les deux pôles de la réflexion, confrontant la conception générale des rapports du "Sage et de l'Empereur" et leur concrétisation particulière durant le règne de Trajan, va-et-vient qui se reflète dans le classement des contributions, et même à l'intérieur de chaque partie.

Celles-ci, au nombre de cinq, vont en effet de la perspective la plus historique aux considérations les plus philosophiques. Après un tableau du cadre socio-culturel à l'époque de Trajan (1. The Greek Social and Cultural World ca 100 A. D., pp. 27-102 : communications de J. Dillon, E. Bowie, T. Schmidt, F.
Brenk et J. Geiger), on passe à un examen des figures du politique, séparant responsable de la cité (2. Plutarch and the contemporary Statesman, pp. 103-160 : A. Pérez Jiménez, L. Van der Stockt et B. Van Meirvenne) et empereur (3. Plutarch and the Emperor, pp. 161242 : M. Beck, G. Roskam, G. Zecchini, M. T. Schettino, C. Pelling et P. A. Stadter). Cette troisième partie, plus nettement encore que les précédentes, oscille entre conception de l'empereur en général et cas particulier de Trajan, et prépare les deux parties suivantes, la quatrième, où le spécialiste de Plutarque a le plus à apprendre, s'attache à l'image officielle voulue par l'empereur lui-même (4. Policy in Stone, pp. 243-278 : G. Koeppel et M. T. Boatwright), tandis que la dernière aborde les aspects les plus philosophiques de la réflexion de Plutarque (5. Plutarch's Philosophy in Context, pp. 279-328 : J. Opsomer, A. Zadorojnyi ${ }^{1}$ et P. Desideri).

Du contenu exact de ces cinq parties, P. A. Stadter donne une description brève et précise dans la seconde partie de son introduction (pp. 13-19), après avoir consacré la première à une "mise en situation" (pp. 1-13), où il rappelle les contacts de Plutarque avec le pouvoir (par ses voyages à Rome, ses amis romains, tous haut placés, ses fonctions delphiques) et les circonstances politiques de l'époque (en particulier au travers de la personnalité des empereurs). Cette seconde partie compense l'absence de résumés en tête de chaque contribution et l'on pourra commodément s'y reporter pour avoir un aperçu du point traité par chaque contributeur. Elle me permettra aussi, sans méconnaître l'intérêt de certaines études de textes précises, comme celle du chapitre 13

1 À la copieuse bibliographie donnée sur le De aud. poet., on ajoutera le long article récent de CHR. BRÉCHET, "Le De audiendis poetis de Plutarque et le procès platonicien de la poésie", Revue de Philologie, 73 (1999) 209-244. 